\title{
Emergence of Public Philosophy in the East-Central European Urban(e) Cultures: a Hungarian Case ${ }^{*}$
}

\author{
BÉLA MESTER \\ Institute of Philosophy, Research Centre for the Humanities, Hungarian Academy of Sciences, 4. Tóth Kálmán st., 1097 Budapest, Hungary \\ Email:mester.bela@btk.mta.hu
}

\begin{abstract}
This article offers an analysis of the nation-city, country-capital relationship in the 19th-century East-Central European nation building in a framework of a case study on the question of the Hungarian Scholarly Society (now: Hungarian Academy of Sciences) about the role and function of the cities and towns of Hungary in the development of the Hungarian national culture. The work of the winner, János Hetényi, published in 1841, has found the equilibrium between the topics of the city and nation as ideal wholes, within a framework of a historical analysis of the urbanity of the public philosophy. This model of the urban(e) nation, organized by the cities as cultural centres was worked out in the optimistic decades of the Hungarian Reform Era (1825-1848), only; on its margins has appeared the known elements of the cultural criticism of the next epochs, such as the topics of a sinful and (ethnically) alien city.
\end{abstract}

Keywords: János Hetényi, nation building, nation-city relationship, public philosophy, urbanity

\section{INTRODUCTION: URBAN HISTORY AS A PHILOSOPHICAL REFLECTION TO THE MODERN NATIONAL CULTURE}

The problem of the relationship of urbanity and philosophy is an ancient and actual question, in the same time. It can be discussed from the perspective of the history of philosophy (for a recent case study see Yilmaz 2017), from the point of view of the self-interpretation of contemporary philosophical schools and disciplines (e.g. for a Heideggerian approach see Conlon 1999; for a phenomenological discussion see Mendieta 2001; and for the point of view of bioethics see Jennings 2001). The role of philosophy in the urbanism is the part of

\footnotetext{
This paper was supported by the Hungarian-Lithuanian joint project Conception of Creative City Within Central Europe: Historical Images and Empirical Indices carried out within the framework of a bilateral agreement of the Hungarian and Lithuanian Academies of Sciences. The text of the present writing is based on the lecture entitled "The National Culture Must Come from the Cities, as the Law Comes from Zion"(1841), presented at a conference organised in Vilnius on 20 April 2017. This writing can be regarded as the second part of my previous paper entitled Cities as Centres of Creativity in the East-Central European Nation Building (Mester 2017).
} 
this topic, as well (for a case study from this point of view see De-Shalit 2003). My researches are focussed on the interpretation of the role of the city in the history of philosophy. In my previous paper (Mester 2017), I offered a historical overview of the turn of the public sphere of philosophy in the emergence of modernity, and the philosophical reflections on the new phenomenon of public philosophy, and its audience, connected to the topic of urbanity from the antique roots to the modern philosophical reflections, and the specialities of the history of philosophy in the East-Central European region, exemplified by Hungarian instances. In the present article, a case study will be offered about the 19th-century theoretical reflection on the role of the cities in the (Hungarian) national culture, formulated by J. Hetényi (1786-1853) who was a Calvinist pastor, and a significant public intellectual of the Hungarian Reform Era.

\section{HETÉNYI'S ANALYSIS OF THE PUBLIC SPHERE}

As the next link of the chain of ideas of the present paper will be offered an analysis of a concrete formulation of the role of cities, written in the 19th century, within the framework of the same discourse that was analysed in my previous published writing. Considering the circumstances of the development and publication of this 19th-century manuscript under discussion, it is clear that this work was not an accident approach of an individual researcher, only, but a part of a well-formulated scientific program of the newly established Hungarian Scholarly Society (now: Hungarian Academy of Sciences). This program was focussed firstly on the development of synchronic and diachronic intellectual inventories of the Hungarian intellectual life. After the series of the scholar dictionaries of the Hungarian vocabularies of all disciplines correlated to the departments of the Academy, the next task was to write the histories and the present grade of the development of the same disciplines in Hungary. An often used method was a competition of the manuscripts as answers for a published question promising an award with a significant amount of money ("100 golden coins"). The question about the influence of our inland cities to the development and politeness of our nation seems to be an odd one out in this series, at first glance, but the term of politeness in the title, and the person of the winner, J. Hetényi, who was a representative of the Hungarian harmonistic philosophy, refers to the well-known, above-mentioned discourse about the national philosophy as a form of the public philosophy.

For describing a realistic picture of Hetényi's situation as a philosopher, who was an applicant of an award for historians, we should consider the internal structure of the Hungarian Scholarly Society (from 1840: Hungarian Academy of Sciences) in the Hungarian Reform Era (1825-1848). However, the Hungarian Scholarly Society was established formally in 1825, and its several functional parts were really working in the first years, as well (e.g. the library was founded in 1826) just its first assembly has made the regulations about the number and title of the departments as late as 1831 . These newly established departments have formulated their first invitations to applications for academic awards. Hetényi has applied successfully to the invitations of both the Department for Philosophy and the Department for History; they were separate ones in his lifetime. (The structure of the departments has been reformed in 1869. From this year till nowadays both the history and philosophy are the fields of Department II.) However, his philosophical writings were usually prize-winners, as well, the correspondent (1836) and regular (1840) memberships of the Hungarian Scholarly Society in the Department for Philosophy were the results of his historical writings. (The first one is the topic of the present article, his work on the history of the Hungarian cities.) From this point of view it is evident that the author, who was prima facie philosopher, has interpreted his task from the point of view of the philosophy of history: 
"A philosophical researcher focuses his attention to the things, which were the most influential to the human and national culture; which were for, or against the development of the peoples. For a narrow-minded antiquary, the history is merely an object of the remembrance, and for him the historiographies are just boring lists of the coronations, deaths, wars and battles of the rulers, $<\ldots . .>$ but for a philosophical mind, discoveries and inventions are greater than the battles, and the changes of the rulers' thrones" (Hetényi 1841: 12-13, my italics).

From this point of view, focussed on the urbanity,

"[T] he cities are meaningful faces and physiognomies of their countryside; a traveller who is a scholar of the soul can decipher a lot from their features. $<\ldots .>$ But the cities are not the mirrors of the present culture of the peoples, only, but they are, above all, giant tools for the refinement of them" (Hetényi 1841: 19, my italics).

Both the urban and national cultures have their ideal-typical forms, their pure concepts, which must be achieved in their history, but the actually existing cities and nations do not always fulfilled their role (for the European context of the city-nation relationship see Ribhegge 2003; Leergen 2015). The city identified with its pure concept is always the main source of the innovation, especially in the antiquity, and in the early modernity. Hetényi has formulated the importance of the consciousness of the pure concept of cities in the societal praxis of the urban citizens from a negative point of view, by emphasizing the consequences of the lack of this social consciousness. Human culture is based on the free urban life, and

"[R]efinement and development of taste were established by the good influence of the cities, as well” (Hetényi 1841: 45).

Consequently,

"in the Hungarian case, the same urban institutions must be the most beneficial tools; a harmonistic and general higher refinement of our nation must be established based on a larger and more purposeful cultivation of the urban culture of the present Hungary" (Hetényi 1841: 19).

This fundamental role of the cities became evident in the early modernity after the urban rebels for liberty, when European cities had become engines of the development in the economy, cultural life, and politics in the same time. Based on his narrative of the European history, Hetényi has formulated normatively the tasks of the Hungarian cities in the history, and has evaluated their fulfilment in different periods, outlining a special national role connected with the development of the Hungarian language in the cultural and scientific scene for them indirectly, as well.

An important part of Hetényi's task was unifying different histories written within the intellectual workshops of different churches and regions into a great national narrative. In this topic, Hetényi was highly cautious, and successful. It is the clearest in the most sensitive early modern epoch, when the results of the Lutheran, Calvinist and Catholic church historians, and "aulic approach" (the view of the Hungarian aristocrats with a loyalty to Vienna as the Hungarian Royal Court), and those of the defenders of the autonomy of the Hungarian Kingdom in the country assembles, and the municipal autonomy of the counties in the boards of the territorial authorities, must be unified within a program of the development of a unified nation with a unified cultural memory, containing all the values and elements of the above-mentioned narratives, with a special regard to the role of the cities. In this situation Hetényi has chosen the optimal solution. After the development of the culture, technology, including economy, the national character of the cultural life incarnated in the usage of the Hungarian language in the high culture will be the third task of the cities. Hetényi argues that all important religious and political groups and regions can demonstrate their commitment to the national development in this epoch giving laudations to the royal politics because of its support of the cities. 
Hetényi’s above-detailed approach was a special application of the "politics of agreement and union of interests", as the central narrative of the Hungarian Reform Era (1825-1848), and this period was almost identical with his active lifetime. This invention of the language of the Hungarian politics was initiated by the count István Széchenyi, and it was based on the 19th-century classical utilitarianism as a frame-theory. A competent authority of the history of Hungarian historiography, Á. R. Várkonyi, has interpreted Hetényi’s and other historical works as an emergence of this political trend within the historiography, in a separate chapter of her standard work, entitled The Idea of the Union of Interests and the Double Task of the Historical Scholarship:

"A view of the history formed by Szontagh's and Hetényi's pens was able to be formulated the noble-origin idea of the union of interests among the historiographical prerequisites" (Várkonyi 1973: 202).

Várkonyi has analysed the role of Hetényi's present writing in a separate subchapter, entitled Historical Variations of the Union of Interests: Hetenyi on the Role of the National Culture (Várkonyi 1973: 202-204). The other author, mentioned by her, G. Szontagh (1793-1858) was a representative of the Hungarian harmonistic philosophy, as well. It is interesting that R. Várkonyi here refers to Hetényi's historical and Szontagh's philosophical work (Szontagh 1843) as examples of the same phenomenon.

This point of view of the union of interests as a political program was important for the 19th-century reviewers, as well. János Czech, one of the reviewers of Hetényi, expressed his opinion that Hetényi's moral statements, in which he had formulated the cases why the Hungarian cities did not fulfill their historical duties, were contrary to the nation-building project, based on the union of interests. According to his notes recorded in the editorial preface by the secretary of the Hungarian Scholarly Society,

"the frequent blaming of the cities [on the pages of Hetényi's work] is an impediment of the approximation and union of the citizens of the country, what is the most important issue of our epoch" (Hetényi 1837: V).

Hetényi's innovative approach of the Hungarian early modernity and the role of the cities in the history of the Hungarian Reformation in his narrative will be discussed in detail later in this article. From his point of view, as a consequence of his analysis of the Hungarian early modernity, emerged a normative approach toward the historical role of the cities in any period of the Hungarian history. The description of the attitudes in the Hungarian cities toward the technical, economical and scientific innovation, and the cultivation of the Hungarian culture have become moral statements about their relationship with their prescribed duties in the history.

\section{TASKS AND DUTIES OF THE TOWNS AND CITIES IN HETÉNYI'S WORK}

From the utilitarian frame-theory of the Hungarian politics of this period, the politics of the "agreement and union of the interests", and from the idea of the "ideal-typical tasks of the cities" an often used pattern of the evaluation of the Hungarian cities in different epochs has been derived. By this evaluation of Hetényi, the worst case is the backwardness in the development of technology and culture, and in the usage of the Hungarian language. In the opinions of Hetényi, these phenomena are three faces of the same thing, a kind of a narrow-minded conservative exclusivity, what is contrary to the calling, or vocation of the ideal-typical city, what is always connected with the innovation and openness:

"This spirit of the bourgeois high culture has not developed in every European city $<\ldots\rangle$ there are states, whose cities do not produce any signs of the above described culture; they are not else than big villages, and their citizens are animated by the spirit of small towns, 
known from the playwrights. Characteristics of the refined bourgeois spirit of the cities are the perfect mutual tolerance, politeness, rule of the common sense over the madness of the power $\langle\ldots\rangle$, the education of mind in sciences and tastes is more difficult in small towns than in bigger and richer cities; their citizens cannot educate each other by refined conversation [...] cannot escape from an infancy of mind. Consequently, their influence on the nation is not beneficial, but often harmful <...>" (Hetényi 1841: 46).

In the framework of the Hungarian political thinking of this epoch, the exclusivity of the cities with defence of their privileges means a declaration that they do not want to participate in the dialogue for a "union of interests"; actually, they want to remain out of the modern nation, to be arrested in a medieval paradigm. In this program for the present and the near future, based on their past, Hungarian cities have three explicit societal and political tasks that must be fulfilled within the lifetime. Hetényi emphasizes:

"The first civic duty is the education of the youth, especially the females" (Hetényi 1841: 232). "The second main civic duty is the industrial development, and demolition of its all barriers" (Hetényi 1841: 234). "The third and greatest civic virtue is the assimilation to the [Hungarian] nationality” (Hetényi 1841: 237).

The most evident role is the second one, the furtherance of the development of the economic life, including both technology and the institutional background (for an overview of the role of the cities in the European modernisation see Lenger 2010). The most important task in this field is to manage the turn of energetics from the traditional, ineffectual technologies to the steam-engines. The second one, which is equally important, is the transformation of the financial system of the economy via savings banks and other new-type institutions. From this respect, the guild system and the defence of the local privileges are the main difficulties for Hungarian cities preventing the fulfilment of their tasks and duties in the life of the nation. The second fundamental mission of cities is the transformation of the educational system of Hungary by the model of the traditions of urban schools. Hetényi here, in terms of the civic and bourgeois education, has unified the tradition of the Greek paideia with the German ideal of Bildungs bürgertum of his lifetime, and the cultural memory of the early modern schools based on the ideal of Humanism, combined with the ideas of the Reformation and the Catholic Revival. Hetényi here referred to the tradition of the gymnasium academicum of the Hungarian Protestant educational system, identifying the institutional background of the needed educational form with the urban secondary school. In his opinion,

"[C]ivic education in our country is in cradle, yet. A sign of this situation is that in our cities the civic schools are absent, with rare exceptions. However, there are two kinds of the educational institutions in these cities that of lower and higher level, elementary and scientific schools, but the most needed ones, namely the secondary or, civic schools do not exist" (Hetényi 1841: 232-233).

The key of the development of the highly needed mass-education and schools for women is this civic school, as well, because this form of the secondary school system can offer experts for the former types of schools. In this respect, at first, in the beginning chapters of his work he speaks about the general importance of the new network of the secondary schools both tailored after the Protestant model of Melanchthon, and the Catholic model developed by the Jesuits (Hetényi 1841: 44-45). Later, he concretises the achievements of this system in the Hungarian case, in the chapters about the Hungarian Reformation, and the Catholic Revival. The function of the new-type secondary schools as the centres of the teachers' training for the elementary schools is formulated most characteristically in this locus: 
"A type of schools, the so-called academicum gymnasium has appeared in the significant cities of our country, earlier by a half century than in Germany. $<\ldots .>$ They were highly frequented because their alumni have received teaching licences. $<\ldots>$ This type of great gymnasia academica, or collegia academica was established by the urban citizens" (Hetényi 1841: 172-173, my italics).

Later, in the concluding chapters, he formulates the requirements of the education of the future based on this fundament:

"Males and females of our bourgeois youth are worthy for $<\ldots>$ a better education. Development of taste is needed, but it can never compensate the lack of the physical, intellectual, and moral education. They must be in harmony for creating an optimal young male and female" (Hetényi 1841: 234).

Hetényi here actually anticipates the societal function of the Central-European secondary school system introduced as late as the second half of the 19th century.

In the second respect, the alien (German) language of the new-type schools is the main difficulty of the fulfilment of the task of the cities. In the time of the Latin schools it was not problematic; but in the lifetime of the author, after the turn of the cultural communication from Latin to the national languages, a new-type school, what is needed by the society from other aspect, will not be attractive for the Hungarian target audience if it will be offered in German (for two recent case studies on the multiethnic cities of the 19th-century Hungarian Kingdom see Crişan 2011; Kurkina 2015). Under these conditions, the cities cannot offer good models, consequently they have lost their potential to be cultural centres of the nation, and Hungary cannot receive the needed models. What is needed, it is the ethnogogia by Hetényi's term, a civic education for the whole of nation based on the model of the civic education of the cities as smaller political entities. This educational program can be based only on the cities, especially on the capital what was under construction, yet, in its ideal-typical form, in Hetényi's lifetime.

Behind the three points of Hetényi, especially the one concerning the national education, there are two implicit tasks of the cities in the national life. The first is a moral turn, in its core the change of the elements of the feudal model of the city tradition. By Hetényi's endeavour, the civic ethos of the modern nation must be based on the free spirit of cities. The second implicit task is to offer a model of the political representation and the government for the whole of the country, based on city traditions, instead of the feudal ones. By the formulation of Hetényi itself, it will be a fundamental turn of the social, economic, cultural and political modernisation. At the final point of this process, the whole of the nation will be characterised by the virtues of the bourgeoisie:

"Our inland cities will be the sources of the public erudition of the country, if their inhabitants will be citizens of the fatherland with bourgeois heart and mouth, i.e. the friends of the national development" (Hetényi 1841: 231).

\section{TOWNS, CITIES, AND THE HUNGARIAN REFORMATION}

In Hetényi's interpretation, the cities, especially their distinguished form, the capital and the whole of the nation are prerequisites of each other in their ideal-typical forms. The meaning of a capital is the representation of a country, and a country can formulate itself only if it has an urban centre (for the European context of the capital-country relationship see Therborn 2002). The term of ethnogogia as a characteristically urbane education can be interpreted as a tool for making polites (citizens) from an amorphous ethnos. According to Hetényi's own words: 
"If there was not ethnogogia, there were no other details of the education, as well, because all the similar things are unified in the national education. The civic education in Hungary must be in harmony with the institutions of Hungary. $\langle\ldots\rangle$ Why the most educated members of our urban bourgeoisie could not assimilate to the [Hungarian] nationality? <...> One of the main causes of the backwardness of our nation is the separation of the German-speaking, and other non-Hungarian urban bourgeoisie; because the national culture must come from the cities, as the Law comes from Zion" (Hetényi 1841: 238-239, my italics).

Consequently, if a national culture cannot come from the cities, neither the city nor the national culture can exist in their ideal typical form, which is "identical with their concepts", by Hetényi's terminology. There is only one period of the Hungarian history in Hetényi's historiography when this conception has been realised, at least, in an embryonic form: the age of the Hungarian Reformation, including the cultural results of the Catholic Revival (for an overview of the relationship of the Reformation and the towns in Hungary see Szelényi 2009). Hetényi's interpretation is close to the later theories of historiography about the Magisterial Reformation (Reformation managed by the urban local authorities, mainly in Central Europe), and the Hungarian concept about the special Hungarian way of urbanisation via "mezőváros" (peasant towns, market towns, or oppida) and their role in the Reformation. The role of this type of the urbanisation in the history of the Hungarian early modernity, and its connection with the Hungarian form of the Magisterial Reformation, partly based on the local authorities of this type of the towns, especially in the case of the Calvinism as the dominant form of the Hungarian Protestantism - it is an often discussed topic of the Hungarian historiography, and history of ideas (for the influence of Calvin in Eastern Europe and in Hungary see Payton 2010). The Hungarian term "mezöváros" does not have a precise and established equivalent in English. However, "oppidum" as the legal term of the late mediaeval and early modern Latin has the same meaning in Western and Central Europe, its societal and economic background can be different in different European regions. The term "market town" was introduced as an equivalent of the same term in the English translations of Hungarian publications on this topic written in the interwar period (for an overview of the recent literature of this type of urbanisation see Németh, Szende 2014). The English term "peasant town" as an equivalent of the same Hungarian term was introduced by the article written by G. Kovács (Kovács 2017).

Hetényi summarises the achievements of the 16th-17th-century Hungarian civilisation as the results of the urban culture of Hungary by the following words:

"Despite of the war period, our bourgeoisie has collected perpetually splendid merits in the development of our common sense, science, morals, and taste. $<\ldots>$ the significant Hungarian cities have established great teaching institutions, nation schools of higher, secondary and elementary level, which did not exist before. They have created book presses, public libraries, and pious, religious foundations. Hungary has been really reborn in this period $<\ldots>$ ". (Hetényi 1841: 170).

\section{CONCLUDING REMARKS: HISTORY OF PHILOSOPHY AND URBAN HISTORY}

From the point of view of Hetényi's double identity as an author of philosophy and historiography it is interesting to see the harmony of his ideas as a philosopher and as a historiographer (It is not a surprising phenomenon in the case of a distinguished author of the so-called Hungarian harmonistic philosophy). It appears in the clearest form in the common patterns of his works of two historical disciplines, history of philosophy and urban history. These common historical patterns are connected with other authors' ones of the discourse of the national 
philosophy as a form of the public philosophy, as well. A few years before Hetényi, P. Almási Balogh has formulated the main historical causes of the backwardness of the Hungarians in the field of philosophy as the lack of the civic liberty, national welfare, and cultivation of the Hungarian language, education, and long stabile peaceful periods (Almási Balogh 1835: 174-190). Considering Hetényi's application for the same academic award, the second best position after Almási Balogh, we can see similar elements (Hetényi 1837: 86-88), and all of them are in the focus of Hetényi's narrative in his above discussed work on the cities, as well, concretised to the problems of the cities as organizing centres of all the parts of the national life, connected with the topic of urbanitas in this discourse detailed above. By other words, Hetényi here fulfils the frame of the general discourse about the urbanity of the new target audience of philosophy, and the societal program of the refinement and politeness of the nation with concrete data and moral evaluation of the history of local cities.

Received 15 September 2017 Accepted 23 November 2017

\section{References}

1. Almási Balogh, P. 1835. "Answer for the Philosophical Question of the Hungarian Scholarly Society”, in Philosophiai Pályamunkák. Budán: Magyar Tudós Társaság, XII-XVI, 1-211.

2. Conlon, J. 1999. "Cities and the Place of Philosophy", Philosophy in the Contemporary World 6(3-4): 43-49.

3. Crişan, M. 2011. "19th Century Oradea: the Reflections of a Multiethnic City in British Travel Literature”, Revista Română de Geografiă Politică 2013(1): 82-99.

4. De-Shalit, A. 2003. "Philosophy Gone Urban. Reflections on Urban Restoration”, Journal of Social Philosophy 34(1): 6-27.

5. Hetényi, J. 1837. “A’ magyar philosophia történetírásának alaprajza [A Sketch of the Historiography of the Hungarian Philosophy]”, Tudománytár 1(2): 76-165.

7. Hetényi, J. 1841. Honi városaink befolyásáról nemzetünk’ kifejlődésére és csinosbulására [On the Influence of Our Inland Cities to the Development Politeness of Our Nation]. Budán: a' Magyar kir. Egyetem’ betüivel (Történettudományi pályamunkák. Kiadja a’ Magyar Tudós Társaság; 1).

8. Jennings, B. 2001. "From the Urban to the Civic: The Moral Possibilities of the City", Journal of Urban Health 78(1): 88-103.

9. Kovács, G. 2017. "From the Guilty City to the Ideas of Alternative Urbanization and Alternative Modernity: Anti-urbanism as a Border-zone of City-philosophy and Cultural Criticism in the Interwar Hungarian Political Thought”, Coactivity: Philosophy, Communication 25: 99-109.

10. Kurkina, A.-T. 2015. "Borderland Identities of Bratislava: Balancing between Slovaks, Germans and Hungarians in the Second Half of the 19th Century", Eurolimes 19: 37-55.

11. Leergen, J. 2015. "The Nation and the City: Urban Festivals and Cultural Mobilisation", Nations and Nationalism 21(1): 2-20.

12. Lenger, F. 2010. "Cities and the Making of Modern Europe", Journal of Urban History 36(1): 99-104.

13. Mester, B. 2017. "Cities as Centres of Creativity in the East-Central European Nation Building" (Forthcoming).

14. Mendieta, E. 2001. "The City and the Philosopher: On the Urbanism of Phenomenology", Philosophy \& Geography 4(2): 203-218.

15. Németh, I. H; Szende, K. 2014. "Research on the Towns of Medieval and Early Modern Hungary Since 1989”, Vana Tallinn 25: 266-294.

16. Payton, J. R. 2010. “Calvin and Eastern Europe: What Happened?” Religion in Eastern Europe 30(2): $10-19$.

17. Ribhegge, W. 2003. "City and Nation in Germany from the Middle Ages to the Present - The Origins of the Modern Civil Society in the Urban Tradition", Journal of Urban History 30(1): 21-26.

18. Szelényi, B. A. 2009. "The New Burgher Revolution in Sixteenth- and Seventeenth-century Partitioned Hungary”, Social History 34(2): 231-248.

19. Szontagh, G. 1843. Propylaeumok a társasági philosophiához, tekintettel hazánk viszonyaira [Propylaea for a Social Philosophy, with Regard to the Conditions of Our Country]. Budán: Emich. 
20. Therborn, G. 2002. "Monumental Europe: The National Years. On the Iconography of European Capital Cities", Housing, Theory and Society 19: 26-47.

21. Várkonyi, Á. R. 1973. A pozitivista történelemszemlélet a Magyar történetírásban. II. A pozitivizmus gyökerei és kibontakozása Magyarországon 1830-1860 [Positivist Approach of the History in the Hungarian Historiography. II. Roots and Emerging of Positivism in Hungary 1830-1860]. Budapest: Akadémiai Kiadó.

22. Yilmaz, M. 2017. "City as the Resource of Philosophy", Uludağ University Faculty of Arts and Sciences Journal of Social Sciences 18(32): 131-139.

BÉLA MESTER

\title{
Viešosios filosofijos atsiradimas Rytų ir Vidurio Europos mies(tie)tiškose kultūrose: Vengrijos atvejis
}

\begin{abstract}
Santrauka
Straipsnyje analizuojamas nacijos ir miesto, šalies ir sostinès santykis kuriantis tautinei savimonei XIX a. Rytų ir Vidurio Europoje. Pasitelkiama atvejo studija, kuria atsakyta ì Vengrijos akademinès draugijos (dabar - Vengrijos mokslų akademija) klausimą apie Vengrijos miestų ir didmiesčių vaidmenį formuojantis Vengrijos nacionalinei kultūrai. Konkurso laimètojo Jánoso Hetényi darbe, paskelbtame $1841 \mathrm{~m}$., surasta pusiausvyra tarp miesto ir nacijos kaip idealiu visumu temų, pateikiant viešosios filosofijos miestietiškumo istorinę analizę. Šis mies(tie)tiškos nacijos, kuriq organizuoja didmiesčiai kaip kultūros centrai, modelis buvo kuriamas tik optimistiniais Vengrijos reformų eros (1825-1848) dešimtmečiais; jo paraštėse pasirode pažįstami kitų epochų kultūrinès kritikos elementai, pavyzdžiui, nuodèmingo ir (etiškai) susvetimejjusio miesto temos.
\end{abstract}

Raktažodžiai: Jánošas Hetényi, tautinès savimonès kūrimas, nacijos ir miesto santykis, viešoji filosofija, miestietiškumas 